\title{
Participation of Youth in Aquaculture
}

\section{Adelodun $\mathrm{OB}^{*}$}

Department of Fisheries Technology, Oyo State College of Agriculture, Igbo-ora, Oyo State, Nigeria

*Corresponding author: Adelodun OB, Department of Fisheries Technology, Oyo State College of Agriculture, Igbo-ora, Oyo State, Nigeria, Tel: +234 805 572 3592 ; Email: adelodunoluwatobi@yahoo.com

Received date: Aug 24, 2015; Accepted date: Sep 15, 2015; Published date: Dec 15, 2015

Copyright: (C) 2015 Adelodun OB. This is an open-access article distributed under the terms of the Creative Commons Attribution License, which permits unrestricted use, distribution, and reproduction in any medium, provided the original author and source are credited.

\begin{abstract}
Aquaculture which deals mainly with the farming of fish has great potential and benefits that ranges from its nutritional purpose to economic benefits, contribution to food security, employment and income generation. As the natural fish stock declines due to over-exploitation, aquaculture has experienced spectacular growth in Nigeria recently. Despite this growth in the sector, fish supply is yet to meet the demand. i.e. as fish demand increases with increase in population, there is no sufficient increase in supply to meet up with the demand. This shows that more attention needs to be paid to this sector in terms of grants permission, improved technologies, orientation programs and also importantly, human resources for the sector to reach its maximum potential.

However, it has been observed that youth involved in aquaculture are few, even as the rate of unemployment keeps increasing. This is as a result of some factors limiting their participation in the sector. To increase the involvement of the youth in the sector, some effective measures such as provision of loan scheme for graduates and school leavers, development of participatory programs and effective extension work need to be adopted. The participation of the youth in aquaculture will not only help the sector to reach its full potential but also contribute to the reduction of unemployment among the youth, as there are opportunities in the sector waiting to be tapped.
\end{abstract}

Keywords: Youth; Aquaculture; Farming; Fish; Human resources

\section{Introduction}

Aquaculture is one of the fastest growing sub-sectors of agriculture with huge potential. It occurs in inland and only recently has the coastal region been the focus of development [1]. The recent popularity of aquaculture in the country is as a result of a decline in the natural stock. As the human population increases and consequent protein demand, the over-exploitation of the natural fish resources has made aquaculture a major option to combat protein malnutrition in the country [1]. The demand for fish protein is about 2.7 million MT and only $800,000 \mathrm{MT}$ is produced locally. It shows that there is still a short in supply of about 1.9million MT [2]. Considering the fact that Nigeria has a large suitable land for fish culture, the potential of the aquaculture sector to meet the fish demand of the increasing population cannot be questioned and over-emphasized. For the potential of this sector to be maximized, there must be a significant increase in the involvement of personnel in every area of the sector.

In Nigeria, aquaculture is still carried out using some physical strength, which declines with age. The youths have desirable qualities that can promote all the sub-sectors of agriculture but most of them have strong apathy toward it $[3,4]$. Youth amounts to about 80 million, representing about $60 \%$ of the total population of the country [5]. This statistics shows that the youth dominates the country in terms of population. Presently, it has been observed that the number of youth involved in aquaculture is very small [6]. Rather than getting involve in farming activities, a vast population of the youth goes in search of the white collar jobs which a decline in its availability has been the experience in recent times. For aquaculture to reach its full potential there should be a considerable and active participation of a high percentage of the youth in the sector. Therefore, this paper aims to evaluate the factors limiting the participation of youth in the aquaculture sector, the ways to improve the participation of the youth in the sector and the potential contribution of aquaculture in the reduction of unemployment among youth.

\section{Factors limiting the participation of youth in aquaculture}

The involvement of the youths in the aquaculture sector is still low and some factors are responsible for this. The factors include:

Expertise: As aquaculture involves the rearing of aquatic organism (fish) in a confined environment, some technicalities are involved in the successful culture of the organisms. Many of the youths lack the skill and knowledge necessary on the field. Even the graduates of the field do not have the practical knowledge, as there may be limit to what can be known in the four corners of the classroom.

Capital investment: Every business sector requires a capital investment and aquaculture sector is not an exception. The high cost of fish feed plays a big part in the requirement of substantial capital to practice aquaculture. Based on this, most youths find it difficult to raise the funds needed to start even when the interest is there.

Preference for the white collar jobs: Ever since the discovery of oil in the country, attention was shifted from agriculture and the sub-sectors as a major source of revenue for the country to oil sector. As a result of this, agriculture started losing its popularity gradually among the youths from one generation to another. The younger generation prefers the "neat" white collar job with the attractive working environment to farming. Therefore, we now have more of the aged ones involve in all types of farming activities including fish farming and this could be a serious threat to the food security of the country. 
Page 2 of 3

Incentives: The amount paid/ given to workers of fish farms as wages or salaries is not encouraging enough to make it lucrative to the youths. Therefore, majority of them see farm jobs as a symbol of poverty.

Lack of encouragement from the government: A large number of farms have failed to attain profitability level in one or more year due to disruptions in their production process [7]. The farmers are not encouraged by the government due to lack of stable financial policies to help the farmers, effective trainings and supply of facilities at subsidized rate among others. All these have not really made the sector appealing to the youths. Thereby still making it difficult to bridge the gap between the fish supply and demand of the country. In order for youth programmes in this sector to be successful, government support is very important [6].

\section{Ways to improve the participation of the youths}

- Entrepreneurship development: Less attention is paid on the entrepreneurship development of the students in our institutions which is seriously telling on the entrepreneurial skills of the eventual graduates. To create the mindset of being enterprising in the youth early enough, entrepreneurship development should be added to the schools' course curriculum. As this will help especially students of aquaculture management to have an awareness of the benefits embedded in their field of study.

- Government should help in the provision of credit scheme for the few youths engaged in aquaculture, as this will encourage others to participate in the sector and also increase the production of the few who are already in it.

- An agricultural production loan scheme aligned with monitoring activities can also be setup for the graduates and school leavers. As the decline in the rate of employment has reached such an alarming proportion, this will give them the opportunity and empowerment to participate in agricultural production in which aquaculture is also a major sub-sector and their activities will be effectively monitored. Aquaculture has the capacity to serve as a veritable tool for the reduction of unemployment in the country.

- Development of aquaculture participatory program can also go a long way in encouraging the youth through trainings, provision of infrastructure, inputs and effective extension work [8]. The programs should be aimed at boosting fish production and youth participation. An example is the "Youth - in - Agriculture" (YIAP) program introduced by the Ondo state government in 2004.

\section{Aquaculture as a tool for the reduction of unemployment}

Awogbenle and Iwuamadi [9] reported that, the youth represent $60 \%$ of the total population of the country as earlier stated. Out of this $60 \%$, a large fraction of about $54.1 \%$ are unemployed while just about $5.9 \%$ are gainfully employed. This has led most youths into cultism, prostitution and street begging, among others. To reduce the level of unemployment in the country, areas which possess high potential of employment opportunities must be looked into and developed. A good example of such is the aquaculture sector.

Fish remains a major source of protein in human diet. According to FDF, there is still a short in supply of about 1.9 million MT in which aquaculture has the capability to meet if more participants are injected into the sector. This shows the big opportunity waiting to be explored by the youth participation in the aquaculture sector. Different units and channels make up the aquaculture sector thereby giving the opportunity to function in different areas within $\mathrm{d}$ sector which will in turns contribute to the development of the sector and also reduce unemployment among youths. Some of the areas in the aquaculture sector that can be explored by the youths include:

- Fish feed suppliers: Fish feed is a major factor in aquaculture as the quality of fish feeds affects fish production. There is an opportunity in the supply of feed ingredients to feed mills and also the supply of the packaged feeds to fish farms.

- Fish processing: Youths can also be involved in the area of value additions and the marketing of the products.

- Consultancy: Those with practical knowledge and skills can serve as consultants to other fish farms.

- Fish farmers: Youth may decide to practice fish farming by going into the production aspect. This will create a source of income and also contribute to the supply of fish to meet the protein demand of the surrounding communities.

- Fish marketers (wholesalers and retailers): Youths can be involved in the distribution channel, from the wholesalers to the retailers till it finally gets to the consumers.

- Inputs supplier: Some can function as suppliers of all inputs needed by the farmer for effective fish production. E.g. fish seeds.

- Researchers etc.

\section{Conclusion}

The potential of aquaculture in the country cannot be overlooked. As the rate of unemployment keeps growing and thereby leading to high crime rate and other social vices among the youth, there is a need to improve the participation of the youth in sectors with high opportunities such as the aquaculture sector. The participation will not only reduce the rate of unemployment but also enables aquaculture sector reach its full potential thereby, contributing to the food security and economic development of the nation.

\section{Recommendation}

In order to improve participation of youth in the aquaculture sector, more attention should be paid to this sector by the government as this will encourage the youth to show interest in the sector. Orientation changing programs should be organized to change the mindset of seeing farming activities as a symbol of poverty but as a viable income generating enterprise.

\section{References}

1. Daramola JA, Osofero SA, Kester CT, Gbadamosi OK (2007) Overview of the Status of Aquaculture in Nigeria with Reference to Ekiti State. Agric J 2: 447-452.

2. FDF (2008) Fisheries Statistics of Nigeria. (4thedn), Nigeria 48.

3. Jibowo AA (1998) Agrological Transmission. The Secret of National Food Surplus. An Inaugural Lecture Delivered on July 11th at the Obafemi Awolowo University, Ile-ife.

4. Adewale JG, Oladejo JA, Ogunniyi LT (2005) Economic Contribution of Farm Children to Agricultural Production in Nigeria: A Case Study of Ekiti State. Journal of Social Science 10: 149-152.

5. Awogbenle AC, Iwuamadi KC (2010) Youth Unemployment: Entrepreneurship Development Programme as an Intervention Mechanism. African Journal of Business Management 4: 831-835.

6. NaFIRRI, (2010) Engaging Youths in Fisheries and Aquaculture. National Fisheries Resources Research Institute. Jinja, Uganda. 
7. Fapohunda OO (2005) Analysis of Bio-Technical and Socio-Economic Factors Affecting Agricultural Production in Ondo State, Nigeria. Ph.D Thesis, Federal University of Technology, Akure, Nigeria.

8. Jibowo AA (2005) History of Agricultural Extension in Nigeria: in SF Adedoyin (Eds), Aricultural Extension in Nigeria. ARMTI, Ilorin. AESON 1-12.
9. Sodique FR (2006) Bee-honey Production: A Strategy for Poverty Alleviation among Youths in Nigeria. Annals of Child and Youth Studies 1: $113-124$. 